\title{
PENGEMBANGAN MATERI AJAR KETERAMPILAN BERBAHASA JAWA RESEPTIF BERBASIS UNGKAPAN TRADISIONAL SEBAGAI MEDIA PENDIDIKAN KARAKTER
}

\author{
Esti Sudi Utami dan Teguh Supriyanto \\ Fakultas Bahasa dan Seni Universitas Negeri Semarang \\ email: esti_sudiutami@yahoo.co.id
}

\begin{abstract}
Abstrak
Penelitian ini bertujuan untuk mengembangkan model materi ajar keterampilan berbahasa Jawa reseptif berbasis ungkapan tradisional sebagai wahana pendidikan karakter bagi siswa SMP. Pendekatan penelitian yang digunakan adalah penelitian dan pengembangan. Produk penelitian ini berupa model materi ajar yang sesuai kebutuhan pembelajaran bahasa Jawa SMP. Materi ajar yang dikembangkan berupa wacana cerita dengan judul peribahasa yang memuat nilai karakter. Materi ajar dikemas dalam bentuk buku kumpulan cerita cekak (cerkak) dan CD film pendek dengan menggunakan bahasa

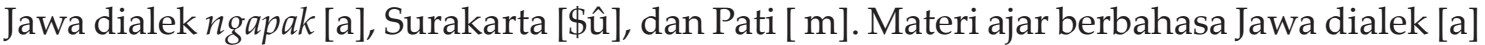
digunakan di SMP wilayah Kebumen, Pekalongan, dan sekitarnya. Materi ajar berbahasa Jawa dialek [\$û] digunakan di Surakarta, Salatiga, Semarang, dan sekitarnya. Materi ajar berbahasa Jawa dialek [ $\mathrm{m}$ ] digunakan di wilayah Pati, Blora, dan sekitarnya. Hasil penilaian produk menunjukkan kategori baik dengan skor 4,35 untuk buku dan 4,50 untuk film pendek. Model materi tersebut dapat digunakan sebagai sarana meningkatkan keterampilan reseptif dan penanaman nilai pendidikan karakter siswa.
\end{abstract}

Kata kunci: materi ajar, keterampilan reseptif, pendidikan karakter

\section{DEVELOPING TRADITIONAL-EXPRESSION-BASED LEARNING MATERIALS FOR RECEPTIVE JAVANESE SKILLS AS CHARACTER EDUCATION MEDIA}

\begin{abstract}
This study aims to develop traditional-expression-based learning materials for Javanese receptive skills as character education media for junior high school (JHS) students. This was a research and development study. The research product was a model of learning materials relevant to Javanese learning needs at JHS. The developed learning materials were in the form of story discourses entitled proverbs containing character values. The learning materials were packed in an anthology of short stories and a short movie CD using

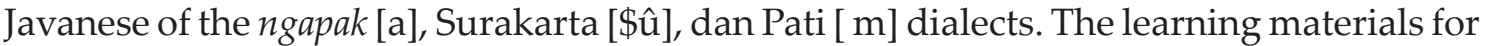
the [a] dialect were used at JHSs in the areas around Kebumen and Pekalongan. Those for the $[\$ \hat{u}]$ dialect were used in the areas around Surakarta, Salatiga, and Semarang. Those for the $[\mathrm{m}]$ dialect were used in the areas around Pati and Blora. The results of the product evaluation showed that the products were good with scores of 4.35 for the book and 4.50 for the short movie CD. The model of the materials could be used as media to improve receptive skills and inculcate values through character education into students.
\end{abstract}

Keywords: learning materials, receptive skills, character education 


\section{PENDAHULUAN}

Perilaku negatif masyarakat Indonesia saat ini semakin tidak terbendung. Hal ini sangat memprihatinkan. Peristiwa kekerasan seperti tawuran, perkelahian, tidak lagi hanya terjadi di lingkungan pelajar dan kampung, tetapi juga antarmahasiswa bahkan anggota dewan yang terhormat. Merosotnya moral ini juga bisa disaksikan di berbagai lini kehidupan mulai dari lingkup keluarga, masyarakat maupun negara. Pameran perilaku hidup seperti penipuan, mabuk-mabukan, ketidakadilan, korupsi, dan lain-lain menjadi tontonan harian bagi anak-anak generasi muda Indonesia lewat media massa.

Kekerasan tidak hanya terjadi secara fisik tetapi juga secara verbal. Saling membully di media sosial bukan merupakan hal tabu. Penelitian Suciati (2014:624-625) menemukan bahwa tayangan komedi televisi yang sering ditonton siswa SMP mengandung tuturan yang bermakna kasar atau kurang santun. Tuturan komedian tersebut mengarah ke tindak kekerasan verbal seperti mengucapkan tuturan yang bermakna mengejek tampang atau fisik seseorang, mengejek orang tua lawan main, mengumbar aib lawan main, merendahkan, dan lain-lain. Tuturan seperti goblok, dasar o'on, gak waras, muka kayakursi somplak, dsb. menjadi tidak asing di telinga anak. Anak dengan mudah meniru dan mengucapkannya kepada lawan tuturnya. Bahkan anak merasa puas dan senang setelah melakukan kekerasan verbal tersebut. Hal ini dapat mempengaruhi sifat atau kepribadian mereka, dan menunjukkan bahwa tindak kekerasan sudah menjadi karakter anak. Gejala krisis moral sepertiini bertolak belakang dan jauh dari persepsi bahwa bangsa Indonesia adalah bangsa yang santun, ramah, dan religius. Predikat tersebut kini telah memudar, hilang, bahkan cenderung berubah ke arah sebaliknya.

Fenomena yang terurai di atas disikapi secara arif dan bijaksana oleh Kementeri- an Pendidikan dan Kebudayaan Nasional. Untuk membangun kembali karakter dan perilaku anak didik, dimasukkanlah pendidikan karakter dalam kurikulum sekolah. Sekolah pada hakikatnya bukanlah sekedar tempat transfer knowledge (Azra, 2012). Selanjutnya dengan mengutip pendapat Fraenkel, Azra menjelaskan bahwa sekolah tidak semata-mata tempat dimana guru mengajarkan pengetahuan melalui berbagai mata pelajaran. Sekolah juga merupakan lembaga yang mengusahakan upaya dan proses pembelajaran yang berorientasi pada nilai. Dengan kebijakan ini, semua mata pelajaran di sekolah (termasuk mata pelajaran muatan lokal bahasa Jawa) wajib melaksanakan pendidikan karakter secara konkret dalam pembelajarannya. Hal ini tertuang dalam Standar Isi Kurikulum 2013 (Permendikbud RI No. 64 tahun 2013) yang meliputi sikap (spiritual dan sosial), pengetahuan, dan keterampilan.

Materi ajar keterampilan reseptif bahasa Jawa merupakan materi strategis untuk pembelajaran berbasis teks. Materi ajar berfungsi sebagai sarana utama dan sumber belajar awal yang dapat membantu siswa dalam mencapai Kompetensi Inti (KI 1-4). Materi ajar selain sebagai sarana pendidikan karakter (KI 1 dan 2) juga merupakan sumber pengetahuan (KI 3) dan bahan pelatihan keterampilan berbahasa (KI 4). Melalui kegiatan membaca atau mendengarkan, siswa mengalami proses memahami, menginterpretasi, mengevaluasi, dan menanggapi informasi/isi teks. Pembelajarannya dilakukan dengan mengintegrasikan keterampilan berbahasa reseptif dan produktif yang disesuaikan kurikulum. Misalnya, guru dapat merancang pembelajaran yang dimulai dari kegiatan membaca dilanjutkan berbicara dan diakhiri menulis. Dengan berpedoman pada kurikulum guru memiliki kebebasan merancang dan melaksanakan pembelajaran berdasarkan kreativitasnya. Cara ini dapat mengurangi 
bahkan menghilangkan cara mengajar dengan buku. Seperti yang dikemukakan Martha (2013:44) bahwa masalah yang sering terjadi adalah guru mengajar dengan buku, sehingga silabus yang dibuat hanya dipakai sebagai kelengkapan administrasi saja. Untuk itu, diperlukan materi ajar berupa teks yang memadukan unsur sikap, pengetahuan, dan keterampilan berbahasa sesuai tuntutan kurikulum. Hal ini menjadi penting karena teks merupakan wujud sarana pendidikan karakter yang bermakna bagi siswa. Abidin (2012:169) menyebutkan bahwa saluran yang paling banyak digunakan untuk mengintegrasikan pendidikan karakter ke dalam pembelajaran membaca adalah melalui bahan ajar dengan muatan karakter berbagai unsur yang dapat diteladani.

Ungkapan tradisional merupakan kristalisasi kebudayaan Jawa dan sumber pendidikan karakter yang layak dan siap ditransfer kepada anak didik. Ungkapan tradisional meliputi paribasan, bebasan, dan saloka (Sukadaryanto, 2001:98). Nilai-nilai yang terkandung dalam ungkapan tradisional merupakan konsepsi-konsepsi yang hidup dalam alam pikiran masyarakat dan dianggap amat mulia karena nilai-nilai itu juga dianggap dapat menjadi penuntun dalam bersikap, berkata, dan berperilaku (Sartini, 2009:4). Ajaran dan nilai-nilai luhur tersebut secara tradisional menjadi panutan bagi masyarakat Jawa. Melalui ungkapan Jawa seperti aja dumeh, jujur bakal mujur, mikul dhuwur mendhem jero, pengembangan sikap positif dan internalisasi nilai-nilai adiluhung dapat terjadi. Bahkan Soehardi (2002:47-53) mengemukakan bahwa nilai-nilai budaya yang tercantum dalam idiom-idiom ungkapan Jawa dan dongeng dapat menyumbang terbentuknya jati diri bangsa atau identitas bangsa Indonesia dalam wacana globalisasi hubungan antarbangsa di dunia.

Perubahan kurikulum saat ini dimaksudkan untuk membentuk sikap positif yang diharapkan. Untuk itu pengembang- an materi yang memuat ungkapan tradisional hendaknya dilakukan oleh guru bahasa Jawa. Hal ini mengingat bahwa corak hidup seseorang ditentukan oleh nilai kebudayaan yang dominan, nilai budaya yang dipandang sebagai nilai yang tertinggi. Bagi orang Jawa, kebudayaan yang dominan adalah kebudayaan Jawa (Idrus, 2012). Muatan budaya dalam materi hendaknya dikemas menjadi teks atau wacana yang menarik dan bermakna bagi siswa. Cara ini perlu dilakukan, karena selama ini siswa hanya dituntut menghafalkan ungkapan tradisional tanpa konteks, sehingga siswa tidak memahami pesan moral nilai-nilai luhur yang terkandung di dalamnya.

Dari pengamatan awal, diketahui adanya ketidaktepatan aplikasi pendidikan karakter dalam pembelajaran bahasa Jawa. Guru mengejawantahkan pendidikan karakter hanya terbatas pada langkah-langkah pembelajaran saja, sehingga tidak ada bedanya dengan mata pelajaran lain. Muatan pendidikan karakter yang mestinya dikembangkan dalam materi pembelajaran belum dilakukan. Materi ajar bahasa Jawa yang benarbenar dirancang dan siap pakai untuk mentransfer nilai-nilai kejawaan belum ada, sementara guru masih mengalami kesulitan untuk merancang sendiri. Hal ini tampak pada kebiasaan guru menggunakan buku yang ada tanpa menelaah muatan nilai pendidikan karakternya. Kenyataan ini perlu mendapat perhatian, mengingat komponen materi ajar merupakan informasi yang harus diserap peserta didik melalui pembelajaran. Siswa harus merasakan manfaat materi setelah mereka mempelajarinya.

Sifat materi ajar dapat dibedakan dalam beberapa kategori yaitu fakta, konsep, prinsip, dan keterampilan. Keterampilan merupakan suatu pola kegiatan yang bertujuan dan memerlukan peniruan serta koordinasi informasi yang dipelajari. Materi ajar bahasa lebih banyak meru- 
pakan keterampilan intelektual karena berhubungan dengan proses berpikir seperti menuangkan gagasan, memecahkan masalah, menilai, menyimpulkan dan lain-lain (Iskandarwassid, 2008:171). Materi ajar bahasa Jawa mencakup keterampilan berbahasa dan bersastra. Pada prinsipnya keduanya merupakan fakta sosial dan sarana komunikasi. Pada satu sisi berbahasa merupakan sarana komunikasi, dan sastra merupakan salah satu hasil budaya yang menggunakan bahasa sebagai alat kreativitasnya. Materi ajar yang dikembangkan untuk berbahasa, diarahkan agar siswa dapat menggunakan bahasa Jawa yang mengandung nilai-nilai kearifan lokal hormat atau sopan santun. Materi ajar bersastra diarahkan agar siswa dapat memperoleh nilai-nilai sastra sebagai unsur budaya Jawa untuk keperluan pembentukan kepribadian dan identitas bangsa. Melalui kegiatan bersastra dapat ditanankan nilai-nilai etika, estetika, sekaligus logika yang dapat dikembangkan dariungkapan tradisional.

Penelitian ini dilakukan untuk menghasilkan model materi ajar bahasa Jawa berupa teks cerita bermuatan ungkapan tradisional sebagai sarana pendidikan karakter yang berbahasa dialek siswa. Teks dikemas dalam bentuk buku cerita dan CD film pendek sebagai materi pembelajaran keterampilan berbahasa reseptif, yang sekaligus dapat digunakan untuk keterampilan berbahasa produktif. Dengan demikian, penelitian ini difokuskan pada pengembangan materi pembelajaran membaca dan mendengarkan. Isi materi memperhatikan muatan isi budaya yang bermakna, berguna, dan menarik (Parera,1996:138). Kebermaknaan tampak pada nilai-nilai luhur yang terkandung dalam ungkapan tradisional. Gunanya untuk membentuk karakter, dan agar menarik perlu dikemas dalam bentuk cerita dengan ilustrasi yang sesuai tingkat usia siswa. Melalui kegiatan pembelajaran membaca dan mendengarkan, siswa dapat menyerap nilai karakter yang terkandung dalam materi cerita. Hal ini penting agar pelaksanaan pembelajaran bahasa Jawa dapat berkontribusi nyata dalam pembentukan karakter anak didik. Harapannya, mereka aktif memahami, menyadari, dan akhirnya mau berperilaku sebagaimana nilai-nilai yang termuat dalam teks.

\section{METODE}

Desain penelitian dirancang dengan menggunakan Research and Development, yaitu suatu proses yang digunakan untuk mengembangkan dan menvalidasi produk-produk pendidikan (Borg dan Gall, 1989: 782). Penelitian ini dijabarkan ke dalam sejumlah langkah kegiatan antara lain: (1) pengumpulan informasi, (2) perencanaan produk, (3) pengembangan rancangan produk awal, (4) pengujian produk awal, (5) revisi produk, (6) pengujian lapangan, (7) revisi produk dan inovasi, dan (8) desiminasi model pengembangan. Penelitian ini bersifat multy years, yang dirancang dalam dua tahap penelitian. Penelitian tahap pertama merupakan tahap pendeskripsian kebutuhan materi ajar keterampilan berbahasa reseptif dan penyusunan materi ajar berbasis ungkapan tradisional sebagai wahana pendidikan karakter. Penelitian tahap kedua dilakukan untuk uji coba materi ajar yang telah dihasilkan.

Subjek penelitian ini adalah guru dan siswa SMP di Jawa Tengah. Beberapa wilayah yaitu Kebumen, Salatiga, Pekalongan, dan Pati dipilih sebagai subjek percontoh (sampel) berdasarkan penggunaan bahasa dialek yang berbeda. Pengambilan sampel di masing-masing wilayah dilakukan secara acak. Instrumen yang digunakan berupa lembar observasi, angket, dan pedoman wawancara. Lembar observasi untuk mengamati kurikulum dan perangkat pembelajaran. Angket dan pedoman wawancara untuk guru dan siswa berisi kebutuhan materi ajar bahasa Jawa SMP berbasis ungkapan tradisional, 
materi ajar bahasa Jawa yang digunakan, dan kesulitan yang dialami.

Pengumpulan data tahap pertama dilakukan dengan menggunakan teknik observasi, angket, dan wawancara mendalam. Observasi dilakukan untuk mengetahui kurikulum dan perangkat pembelajaran membaca dan mendengarkan yang digunakan di SMP. Angket dan wawancara dilakukan untuk menjaring data kebutuhan materi ajar membaca dan mendegarkan berbasis ungkapan tradisional Jawa bagi guru dan siswa.

Proses analisis dilakukan dengan cara mengorganisasikan dan mengelompokkan data yang dikumpulkan sesuai dengan sifat dan kategori data yang ada. Langkah ini merupakan langkah reduksi data dan sekaligus penyajian data. Untuk menghindari data yang bias dilakukan pemerikasaan keabsahan data dengan cara perpanjangan keikutsertaan, trianggulasi, baik trianggulasi teknik maupun sumber data, pengecekan sejawat, dan kecukupan referensial (Moleong, 1995: 175-179). Model analisis yang dilakukan pada tahap ini adalah analisis interaktif, yakni analisis data melalui empat komponen analisis: reduksi data, sajian data, penarikan simpulan, dan verifikasi dilakukan secara simultan (Miles \& Huberman, 1992). Proses analisis ini difokuskan pada kebutuhan guru dan siswa untukmenyusun materi ajar keterampilan membaca dan mendengarkan SMP berbasis ungkapan tradisional Jawa.

\section{HASIL DAN PEMBAHASAN}

Penelitian ini menghasilkan model materi ajar pembelajaran keterampilan berbahasa reseptif yang memanfaatkan ungkapan tradisional Jawa sebagai wahana pendidikan karakter. Materi ajar berupa teks cerita sebagai bentuk pengintegrasian komponen sikap, pengetahuan, dan keterampilan berbahasa reseptif. Materi dikembangkan berdasarkan kebutuhan siswa dan guru.

\section{Kebutuhan Siswa}

Hasil penelitian menunjukkan bahwa bahasa pengantar yang digunakan siswa SMP di Jawa Tengah dalam kehidupan sehari-hari adalah bahasa Jawa yaitu sebesar $88,2 \%$. Penggunaan bahasa Jawa tersebut untuk berkomunikasi baik dalam ranah keluarga, keketetanggaan, maupun bermasyarakat. Dari jumlah tersebut $96 \%$ siswa menggunakan bahasa Jawa ragam ngoko. Mereka tidak mengalami kesulitan dalam berkomunikasi bahasa Jawa dalam ragam ngokodi lingkungannya. Untuk itu yang sangat dibutuhkan siswa saat ini adalah materi pembelajaran bahasa Jawa yang dapat melatih dan meningkatkan pengetahuan dan keterampilan berbahasa ragam krama. Hal ini sesuai tututan Kurikulum Mulok Bahasa Jawa SMP 2013 yang menyatakan bahwa penguatan materi dilakukan dengan memperhatikan penggunaan bahasa Jawa ragam ngoko dan krama dengan mempertimbangkan keberadaan dialek masing-masing daerah. Materi kebahasaan yang berkaitan dengan unggah-ungguh tidak disajikan secara khusus pada aspek pengetahuan (KI 3), tetapi berupa aksi sebagai manifestasi kesantunan berbahasa yang menjadi bagian dari aspek sosial (KI 2) dan aspek keterampilan (KI 4). Materi tersebut tercermin dalam penggunaan bahasa sehari-hari yang diajarkan melalui keteladanan dan pembiasaan pada proses pembelajaran yang dimulai dari keterampilan berbahasa reseptif dan dilanjutkan keterampilan berbahasa produktif.

Dari empat keterampilan berbahasa yang dipelajari, siswa mengaku lebih senang mendengarkan dan membaca dibandingkan berbicara dan menulis. Namun demikian, karena materi yang digunakan guru berbahasa dialek [ $[$ ], mereka (terutama siswa yang berada di wilayah Kebumen, Pekalongan, dan Pati) mengalami kesulitan. Hal ini tentu tidak menjadi masalah bagi siswa yang di wilayah sekitar Salatiga dan Semarang. 
Dalam pelajaran keterampilan mendengarkan dan membaca (84\%) siswa lebih suka wacana berupa cerita. Sebagian besar siswa $(76 \%)$ suka tokoh manusia. Untuk pembelajaran mendengarkan siswa mengharapkan materi dikemas dalam bentuk audio visual. Alasannya mereka tidak hanya mendengarkan saja tetapi dapat melihat perilaku tokoh cerita sehingga dapat membantu pemahamannya.

Terkait dengan pendidikan karakter, $84 \%$ siswa mengaku mengetahui bahwa ungkapan tradisional Jawa itu berisi nasehat. Namun ketika ada wacana yang menggunakan ungkapan tersebut, siswa tidak memahami maksudnya. Dalam pembelajarannya $88,4 \%$ siswa menginginkan materi ungkapan tradisional tersebut tidak dihafalkan melainkan dibuat cerita. Sebesar 83,3\% siswa menginginkan bahasa pengantar yang digunakan dalam cerita adalah bahasa dialek setempat.

Berdasarkan uraian di atas maka dibutuhkan pengembangan materi pembelajaran keterampilan reseptif baik mendengarkan maupun membaca yang dikemas dalam bentuk cerita. Cerita yang dikembangkan memuat nasehatnasehat yang bersumber dari ungkapan tradisional Jawa. Materi keterampilan membaca berbentuk buku cerita pendek, sedangkan materi keterampilan mendengarkan berbentuk film pendek. Kegiatan membaca dan mendengarkan cerita merupakan salah satu kegiatan yang menyenangkan bagi siswa. Mereka selain merasakan manfaat materi yang dipelajari dari segi isi, juga memperoleh hiburan dalam proses mempelajarinya. Dengan materi tersebut, siswa selain mendapat pelatihan mendengarkan dan membaca mereka juga memperoleh pesan moral atau nilai pendidikan karakter yang termuat dalam wacana cerita. Hal ini sesuai dengan Iskandarwassid (2008:171) yang mengatakan bahwa materi ajar merupakan informasi yang harus diserap peserta didik melalui pembelajaran yang menye- nangkan. Model pengembangan materi ini merupakan pengintegrasian materi pendidikan karakter dalam pembelajaran bahasa Jawa SMP. Kurikulum Mulok Bahasa Jawa SMP 2013 menyebutkanbahwa pemanfaatan sastra Jawa modern sebagai hasil karya sastra baik tulis maupun lisan dapat digunakan untuk pembentukan karakter yang njawani. Harapannya cara berpikir, ucapan, dan perilaku siswa akan terbentuk melalui materi pembelajaran keterampilan reseptif tersebut. Materi yang dimaksud berbentuk cerita yang di dalamnya terdapat wacana dialog, sehingga dapat menjadi model penggunaan bahasa Jawa yang senyatanya ada di masyarakat.

\section{Kebutuhan Guru}

Pembelajaran bahasa Jawa SMP di Jawa Tengah tahun ajaran 2013/2014 masih menggunakan KTSP. Ada 20\% sekolah yang ditunjuk dinas propinsi untuk melaksanakannya, tetapi tidak terlaksana karena belum ada kurikulumnya. Kurikulum 2013 secara serentak dilaksanakan tahun ajaran 2014/2015 untuk kelas VII dan VIII. Alokasi waktu yang tersedia 2 jam pelajaran. Kendala yang dialami guru antara lain kesulitan membuat RPP, kebingungan melaksanakan penilaian, juga belum tersedianya materi ajar. Guru menggunakan buku paket yang digunakan tahun ajaran 2013/2014 yaitu Marsudi Basa lan Sastra Jawa terbitan Erlangga, Padha Bisa Basa Jawa terbitan Yudhistira. Buku paket ini digunakan se-Jawa Tengah. Buku tersebut berbahasa Jawa ragam ngoko dialek [ə]. Selain buku paket, guru juga menggunakan LKS buatan MGMP. Namun, bahasa yang digunakan juga bahasa dialek [ [こ] ragam ngoko dengan tema-tema umum seperti ekonomi, iptek, hiburan, tranportasi, dan sebagainya. Di kalangan guru bahasa Jawa masih ada persepsi bahwa dialek [ə] dianggap sebagai bahasa Jawa standar yang harus diajarkan kepada siswa. Hal ini tentu tidak 
sesuai teori pembelajaran bahasa, materi ajar mestinya bahasa yang nyata hidup di masyarakat lingkungan siswa. Terungkap pula bahwa materi pembelajaran mendengarkan di wilayah Kebumen ada yang memanfaatkan CD berbahasa Indonesia. Hal ini tentu tidak sesuai dengan tujuan pembelajaran bahasa Jawa. Perlu disadari, bahwa saat ini fungsi utama bahasa Jawa adalah sebagai sarana komunikasi kehidupan sehari-hari di masyarakat. Oleh karena itu, bahasa Jawa yang tepat untuk diajarkan adalah dialek setempat.

Berkaitan dengan pengintegrasian pendidikan karakter dalam pembelajaran bahasa Jawa, diketahui bahwa buku dan LKS tersebutbelum memanfaatkan ungkapan tradisional. Mereka mengimplentasikan pendidikan karakter terbatas pada langkah-langkah pembelajaran dalam RPP dengan metode saintifik. Padahal berdasarkan wawancara diketahui bahwa penggunaan ungkapan tradisional oleh masyarakat masih ada dan di masing-masing wilayah mempunyai kecenderungan yang berbeda. Masyarakat di wilayah Kebumen menggunakan ungkapan tradisional esuk dhele sore tempe, jer basuki mawa beya, ngubak-ubak banyu bening. Wilayah Pekalongan menggunakan becik ketitik ala ketara, mburu uceng kelangan dheleg, adol abab. Wilayah Salatiga menggunakan jujur mujur, medhit kejepit, sapa nandur bakal ngundhuh, aja dumeh. Wilayah Blora, Pati menggunakan kebo nusu gudel, kriwikan dadi grojogan, asu belang kalung wang, ula marani gebug, rukun agawe santosa. Berdasarkan kenyataan ini, ungkapan tradisional dapat diintegrasikan dalam wacana sebagai materi keterampilan berbahasa reseptif. Dengan harapan makna ungkapan Jawa tersebut dapat dimengerti secara mudah dan dapat menjadi contoh dalam kehidupan seharihari. Guru (80\%) berharap penelitian ini menghasilkan materi berupa cerita yang memuat nilai karakter, dan $92 \%$ setuju materi dikembangkan dari ungkapan tradisional sebagai tema cerita.
Dalam strategi pembelajaran bahasa terdapat strategi meniru (Suciati, 2014:626). Dengan membaca, mendengarkan, dan menonton tuturan dan perilaku yang ada dalam materi ajar, siswa banyak memperoleh kosa kata baru yang dapat menjadi perbendaharaan kosakata bagi perkembangan bahasanya. Mereka dapat mengingat dan meniru kesantunan berbahasa dan moral yang dilatihkan sehinggamenjadi anak yang berkarakter. Dengan menggunakan dasar KI dan KD yang ada, diharapkan guru dapat membelajarkan bahasa Jawa bersumber pada teks cerita tersebut baik lisan maupun tulis sesuai dengan silabus dan rancangan pembelajaran yang dikembangkan.

\section{Prinsip Pengembangan Materi Ajar Ke- terampilan Berbahasa Reseptif Berbasis Ungkapan Tradisional sebagai Wahana Pendidikan Karakter}

Materi/bahan ajar merupakan sarana dan sumber belajar yang dapat membantu siswa dalam mengembangkan kompetensinya di sekolah. Oleh karena itu, diperlukan bahan ajar yang sesuai dengan kebutuhan siswa dan guru. Bahan ajar harus sesuai dengan kurikulum dan moralitas masyarakatnya. Bahan ajar yang memuat moralitas menjadi sarana pendidikan karakter. Selayaknya hasil budaya, moralitas masyarakat diwariskan secara turun-temurun dan dipegang teguh dalam kehidupan masyarakat. Materi ajar yang dimaksud berbentuk teks cerita. Menurut Sukadaryanto (2013:202) materi ajar yang berbentuk cerita tidak saja untuk menghibur tetapi dapat mentransfer nilai-nilai moralitas yang terkandung di dalamnya.

Keterampilan berbahasa reseptif pada hakikatnya merupakan kemampuan atau proses decoding, kemampuan untuk memahami bahasa yang dituturkan oleh pihak lain (Nurgiyantoro, 2001:231). Keterampilan berbahasa reseptif meliputi keterampilan mendengarkan/menyimak 
dan membaca. Keduanya bersifat menerima. Perbedaanya adalah menyimak menerima informasi dari sumber lisan, sedangkan membaca dari sumber tertulis (Tarigan, 2008:4). Oleh karena itu wacana materi membaca dan mendengarkan yang dikembangkan berbentuk cerita dengan tema ungkapan tradisional Jawa. Dengan ajaran berupa nasehat/saran/ petuah ini diharapkan dalam dirinya (siswa) terdapat jejeg adeging uripe marga batine ora tau gonjing, ora tau tidha-tidha, ora tau was sumelang, lan ora tau kegiwang marang samubarang (dapat hidup tegak karena jiwanya tidak pernah galau, tidak pernah ragu-ragu, tidak pernah cemas, dan tidak pernah silau terhadap apa pun (Padmosoekotjo,1960:61-76). Untuk itu, pengembangannya perlu mempertimbangkan prinsip-prinsip berikut: (1) materi berdasar kurikulum, (2) materi berbentuk teks cerita, (3) materi memanfaatkan ungkapan tradisional, (4) materi memuat nilai karakter, (5) materi menggunakan dialek siswa, (6) materi berbentuk tek lisan dan tulis.

\section{Materi Berdasar Kurikulum}

Pengembangan materi ajar keterampilan berbahasa reseptif mengacu pada kurikulum yang berlaku yaitu Kurikulum 2013 Mulok Bahasa Jawa SMP. Komponen kurikulum yang harus diperhatikan meliputi standar kompetensi lulusan yaitu (1) sikap, (2) pengetahuan, dan (3) keterampilan.

Komponen sikap yang dikembangkan dalam materi ajar merupakan ajaran hidup. Ajaran tersebut memuat contoh perilaku atau sikap baik dan buruk yang mengacu pada tuntunan agama dan norma sosial. Sikap baik menjadi teladan positif yang diwariskan kepada siswa, sedangkan perilaku buruk merupakan contoh negatif yang harus dihindari siswa. Terapan contoh perilaku tersebut dikembangkan dalam unsur instrinsik pembangun cerita seperti perwatakan tokoh, alur cerita, dan sebagainya. Dengan memahami materi ini, diharapkan perilaku kehidupan siswa sesuai dengan norma yang belaku di masyarakat. Diharapkan mereka dapat memilah, memilih, dan meneladani perilaku yang sesuai untuk membentuk jati diri dan kepribadiannya. Contoh perilaku tersebut mengacu pada sikap spiritual dan sikap sosial yang dirumuskan dalam kompetensi inti 1 dan 2 .

Komponen pengetahuan yang dikembangkan dalam materi ajar keterampilan berbahasa reseptif merupakan terapan teori bahasa dan teori sastra. Terapan teori bahasa tampak pada penggunaan bahasa yang baik dan benar dalam cerita. Terapan teori sastra tampak pada pembangunan unsur-unsur instrinsik dalam cerita. Dengan demikian, komponen pengetahuan tentang kaidah kebahasaan dan kesastraan tidak disajikan atau dipahami sebagai pengetahuan secara teoretis, melainkan melalui terapannya dalam pengembangan wacana. Hal ini sesuai dengan kurikulum (KI 3), bahwa aspek teori tidak hanya berhenti pada tataran pengetahuan tetapi sebagai action penggunaan bahasa dan sastra. Dengan demikian, selain memudahkan pemahaman siswa terhadap isi wacana, juga memberikan pengetahuan tentang penggunaan bahasa melaui keteladanan dan pembiasaan pada setiap kesempatan dalam pembelajaran.

Komponen keterampilan difokuskan pada peningkatan keterampilan berbahasa reseptif. Wacana materi untuk keterampilan membaca dan mendengarkan hendaknya mengacu pada kurikulum (KI 4). Oleh karena itu, wacana materi ajar yang dikembangkan hendaknya menarik dan bermakna sehingga dapat mendorong minat siswa untuk selalu ingin membaca dan mendengarkan dalam pembelajaran. Kuantitas dan kontinuitas kegiatan membaca dan mendengarkan diharapkan dapat meningkatkan keterampilan berbahasa reseptif mereka. 


\section{Materi Berbentuk Teks Cerita}

Materi ajar kurikulum 2013 berbasis teks. Oleh karena itu materi hendaknya dikemas dalam bentuk teks cerita. Cerita yang dikembangkan merupakan penuturan tentang suatu kejadian. Kejadian itu dapat bersumber dari kehidupan seharihari baik pengalaman pribadi maupun orang lain. Dari cerita itu dapat diketahui dengan mudah tentang bagaimana, dimana, dan apa yang dialami pelaku cerita dari awal sampai akhir. Melalui wacana cerita selain meningkatkan keterampilan berbahasa reseptif, siswa juga memperoleh pendidikan karakter dan hiburan.

Cerita hendaknya sesuai tingkat perkembangan kognitif anak. Untuk itu pengembangannya perlu memperhatikan hal-hal berikut: (1) bertema kehidupan yang terkait dengan dunia anak, (2) masalah yang diangkat tunggal, (3) alur cerita lurus atau tunggal, (4) tokoh mudah dikenali, dan melibatkan tokoh muda dan tua (untuk kepentingan pendidikan unggah-ungguh basa), (5) penokohan sederhana, (6) pesan yang disampaikan mudah dicerna, dan (7) bahasa sesuai dengan tingkat perkembangan bahasa anak.

Agar menjadi wacana cerita yang baik dan menarik dalam, pengembangannya hendaknya juga memperhatikan komponen kesastraan seperti penganalan, penggawatan atau pengenalan masalah, klimaks atau puncak masalah, anti klimaks atau meredanya masalah, dan penyelesaian masalah.

\section{Materi Memanfaatkan Ungkapan Tra- disional}

Ungkapan tradisional bagi masyarakat Jawa merupakan warisan lisan yang telah melembaga dalam kehidupan sehingga bersifat collectivity. Warisan tersebut sebagai kebijaksanaan lokal yang dapat dipergunakan sebagai patokan hidup dalam bertingkah laku baik secara individual maupun sosial. Nilai-nilai moral yang terkandung di dalamnya merupakan norma atau konsepsi ajaran baik mengenai perbuatan, sikap, akhlak, budi pekerti yang berlaku dan diyakini serta diterima dalam kehidupan mayarakat Jawa. Hal ini dapat menjadi panutan (penuntun) dalam berpikir, bersikap, berkata, dan berperilaku. Ungkapan Jawa yang berisi ajaran luhur tersebut dapat dikembangkan sebagai tema, menjadi gagasan pokok untuk membangun unsur-unsur intrinsik cerita. Seperti temuan penelitian Widyastuti (2012) dalam ungkapan tradisional terdapat tema pengendalian diri, etika berumah tangga, etika kepemimpinan, etika berbangsa dan bernegara. Melalui cerita yang bertema ungkapan tradisional ini siswa dapat memperoleh pendidikan karakter. Misalnya cerita bertema ungkapan becik ketitik ala ketara dapat dikembangkan unsur pendidikan kejujuran, kepedulian, ketakwaan, tanggung jawab, dan sebagainya.

\section{Materi Memuat Nilai Karakter}

Pengembangan materi pembelajaran membaca dan mendengarkan hendaknya mengintegrasikan pendidikan karakter. Pengintegrasian ini sangat efektif, karena pendidikan karakter tidak dipelajari secara terpisah melainkan diperoleh melalui kegiatan memahami teks cerita. Nilai karakter yang dikembangkan bersumber dari ungkapan tradisional. Cerita yang bermuatan nilai-nilai karakter Jawa tersebut bersifat mendidik dan membangun karakter anak, karena dapat berfungsi meningkatkan kepekaan rasa pada budaya bangsa sendiri, memberi kepuasan batin, memahamkan nilai kemanusiaan. Melalui pemahaman cerita siswa memperoleh pengetahuan tentang kecakapan emosional, sosial, dan spiritual.

Pengembangannya perlu mempertimbangkan: (1) nilai karakter yang akan diajarkan kepada siswa dan (2) ungkapan tradisional Jawa yang masih dipakai masyarakat lingkungan siswa. Perilaku atau sikap negatif siswa merupakan hal 
yang mendesak untuk dicarikan solusinya. Penentuannya dapat dilakukan oleh guru bersama masyarakat, dengan cara mengidentifikasi dan membuat skala prioritas sikap negatif tersebut. Langkah selanjutnya menentukan ungkapan yang sesuai dan mengembangkannya menjadi wacana cerita.

\section{Materi Menggunakan Dialek Siswa}

Bahasa pengantar yang digunakan dalam materi ajar keterampilan berbahasa reseptif hendaknya memperhatikan bahasa Jawa dialek siswa. Kekhasan masingmasing dialek yang digunakan berkomunikasi masyarakat di lingkungan siswa, harus dimanfaatkan dalam pengembangan materi ajar baik membaca maupun mendengarkan. Penggunaan dialek akan memudahkan mereka dalam memahami, menginterpretasi, dan menanggapi pesan yang disampaikan. Hal ini menjadi perhatian karena tujuan kegiatan membaca dan mendengarkan adalah memahami isi wacana secara cepat, tepat, dan akurat. Misalnya, materi ajar yang digunakan di wilayah Banyumas menggunakan bahasa khas ngapak seperti penggunaan kata nyong, maring, gole, di wilayah Pati menggunakan kekhasan klitik em, partikel leh, thik, ga, a..., dll., sedangkan di Solo menggunakan partikel $t a$, di Pekalongan memiliki kekhasan kata pok. Penggunaan bahasa dialek dalam wacana tersebut hendaknya juga memperhatikan komponen kebahasaan seperti diksi, stuktur, (pelafalan dan intonasi untuk keterampilan mendengarkan), dan (ejaan untuk keterampilan membaca).

\section{Materi Berbentuk Teks Lisan dan Tulis}

Materi keterampilan mendengarkan dikemas dalam bentuk CD film pendek. Dengan melibatkan pancaindera pendengaran dan penglihatan dapat meningkatkan konsentrasi, sehingga pemahaman dan daya ingat siswa terhadap pesan yang disampaikan akan maksimal. Selain itu siswa juga dapat menghubungkan fakta dan konsep. Sukiman (2012:32) mengatakan bahwa $90 \%$ hasil belajar seseorang diperoleh melalui indera pandang, $5 \%$ melalui indera dengar, dan 5\% lagi melalui indera lainnya. Pendapat ini diadopsi untuk kepentingan pengembangan materi ajar pembelajaran mendegarkan bahasa Jawa. Dengan demikian, hasil pemahaman wacana lisan yang hanya $5 \%$ itu terbantu oleh gambar gerak yang dilihatnya. Oleh karena itu materi keterampilan mendengarkan hendaknya berbentuk audio visual, bukan sekedar rekaman suara. Agar tampilan audio visual menarik dan mudah untuk didengarkan perlu memperhatikan komponen durasi film, backsound, kualitas gambar, kualitas suara, dan kesesuaian pemeran dengan karakter dalam cerita.

Materi keterampilan membaca selain memperhatikan isi materi seperti yang tertuang pada prinsip (butir-butir di atas), juga perlu memperhatikan aspek tampilan atau penyajian fisik. Oleh karena itu, agar materi membaca yang berbentuk cerkak ini menarik dan mendorong siswa suka membaca hendaknya juga memperhatikan ukuran dan jenis kertas yang digunakan, grafika seperti jenis huruf dan ukuran huruf, desain ilustrasi seperti jenis gambar, warna, dan sebagainya. Di samping itu, pengemasannya hendaknya memenuhi struktur buku seperti kata pengantar, daftar isi, dan sebagainya.

\section{Produk Pengembangan Materi Ajar Ke- terampilan Berbahasa Reseptif}

Materi ajar keterampilan berbahasa reseptif yang dihasilkan penelitian ini berbentuk wacana cerita bertema ungkapan tradisional. Cerita menggunakan tokoh manusia. Tokoh melibatkan usia tua dan muda sehingga terdapat model penggunaan bahasa yang santun dalam dialog. Hal ini sangat dibutuhkan siswa, mengingat mereka masih mengalami kesulitan jika berkomunikasi dengan 
ragam krama. Pengintegrasian nilai karakter dalam wacana cerita bersumber dari peribahasa yang mengarah pada pembentuk kepribadian dan penguat jatidiri masyarakat Jawa.

\section{Materi Ajar Keterampilan Membaca}

Materi ajar keterampilan membaca yang dihasilkan berupa dua buah buku. Buku pertama berjudul Ula Marani Gebug merupakan kumpulan cerkak. Buku tersebut berisi empat buah cerita yang dikembangkan dari peribahasa ula marani gebug, kebo usu gudel, kriwikan dadi grojogan, dan asu belang kalung wang. Cerita menggunakan dialek Pati [m]. Buku bacaan kedua berisi satu cerita yang dikembangkan dari peribahasa wong jujur bakal mujur dengan dialek Surakarta/Solo [\$û]. Buku dilengkapi ilustrasi gambar berwarna.

Muatan nilai pendidikan karakter yang terdapat dalam cerita antara lain kedisiplinan/patuh pada aturan, kegigihan/pantang menyerah, kejujuran, rendah hati, hidup sederhana, tanggung jawab, bersyukur kepada Tuhan, berserah diri pada Tuhan, meminta pengampunan kepada Tuhan, meminta maaf kepada sesama, konservasi budaya (berkaitan tembang, wayang, batik), dan sebagainya.

\section{Materi Ajar Keterampilan Mendengarkan}

Materi ajar keterampilan berbahasa mendengarkan yang dihasilkan penelitian ini berupa CD film pendek dengan bahasa dialek [a] dengan durasi waktu 9 menit. Cerita dikembangkan dari paribasan becik ketitik ala ketaradan esuk dhele sore tempe. Cerita diiringi tembang-tembang Jawa dan ilustrasi permainan tradisional Jawa.

Nilai pendidikan yang terintegrasi dalam cerita ini adalah nilai kejujuran, kemandirian, tanggung jawab, cinta damai, semangat kebangsaan, cinta tanah air, kerukunan, saling menghargai antar sesama, tekun beribadah, dan sebagainya.

\section{Validasi Produk}

Berdasarkan validasi produk materi ajar keterampilan membaca diperoleh skor rata-rata 4,35 yang termasuk kategori baik. Skor maksimal adalah 5. Artinya bacaan berbahasa Jawa berbasis ungkapan tradisional yang dihasilkan ini layak digunakan sebagai bahan/materi ajar. Hasil validasi digunakan sebagai dasar perbaikan terhadap produk. Saran/masukan perbaikan yang diusulkan validator seperti berikut. Pertama, sajian cerita diharapkan tidak terlalu serius. Cerita hendaknya memasukkan unsur humor sehingga secara psikologis cerita mudah dicerna dan muatan nilai karakter yang ingin disampaikan mudah dipahami siswa. Kedua, bagian akhir cerita diberi makna kata-kata sukar.

Contoh perbaikan teks yaitu dimunculkan tuturan berikut. Semula pernyataanpernyataan ini tidak ada dalam draf cerita yang bertema peribahasa asu belang kalung wang.

Anak: "Wah kula kepengin dados gug gug belang, haha...."

Bapak: "Lho, lho, piye leh Ndhuk, kok gug gug? Paribasan ya gak pareng diowahi, ya kudu ajeg a...."

\section{Materi Ajar Keterampilan Mendengarkan}

Validasi produk film pendek ini dilakukan dua tahap, yaitu uji validasi naskah cerita dan validasi film. Uji validasi naskah dilakukan sebelum pengambilan gambar dengan tujuan mengurangi kesalahan produk film. Hasil validasi naskah berupa perbaikan penggunaan kekhasan diksi dialek Banyumasan dan bentuk naskah. Bentuk naskah sebelum divalidasi masih cenderung sebagai naskah sandiwara audio bukan audio visual. Oleh karena itu, naskah diubah sesuai dengan aturan pembuatan naskah film sehingga pengambilan gambar tidak perlu berulang-ulang.

Hasil penilaian produk film pendek termasuk kategori baik. Ada kritik berkaitan 
dengan kualitas gambar dan kualitas suara, tetapi secara keseluruhan film pendek ini dinilai layak digunakan sebagai materi pembelajaran mendengarkan. Rerata skor validasi adalah 4,50 sehingga tidak perlu dilakukan perbaikan.

\section{SIMPULAN}

Berdasarkan hasil penelitian dapat disimpulkan hal-hal sebagai berikut. Pertama, kebutuhan siswa SMP dalam pembelajaran keterampilan berbahasa reseptif adalah materi ajar berbahasa Jawa dialek setempat sehingga mudah dipahami. Materi yang diinginkan berbentuk teks cerita. Kedua, kebutuhan guru dalam pembelajaran keterampilan berbahasa reseptif adalah materi berupa teks yang mengintegrasikan nilai karakter sesuai tuntutan kurikulum 2013. Pengembangan wacana memanfaatkan ungkapan tradisional Jawa. Ketiga, produk materi ajar keterampilan berbahasa reseptif yang dihasilkan berupa buku cerita pendek dan $\mathrm{CD}$ film pendek. Materi disusun berdasarkan prinsip-prinsip berikut: (a) berdasar kurikulum, (b) berbentuk teks cerita, (c) memanfaatkan ungkapan tradisional,(d) memuat nilai karakter, (e) menggunakan dialek siswa, dan (f) berbentuk teks lisan dan tulis. Keempat, hasil penilaian produk termasuk kategori baik, yaitu skor ratarata 4,35 untuk materi ajar keterampilan membaca dan 4,50 untuk materi ajar keterampilan mendengarkan. Skor maksimal adalah 5 .

\section{UCAPAN TERIMA KASIH}

Artikel ini ditulis berdasarkan hasil penelitian Hibah Bersaing tahap pertama tahun 2014 yang didanai oleh DP2M DIKTI. Ungkapan terima kasih diucapkan kepada: (1) Direktur DP2M DIKTI yang telah menghibahkan dana penelitian melalui BOPT Universitas Negeri Semarang, (2) Rektor Universitas Negeri Semarang yang telah memberikan kesempatan penelitian ini melalui Ketua LP2M, (3) para guru dan siswa SMP di Jawa Tengah yang telah bekerjasama dalam penelitian ini.

\section{DAFTAR PUSTAKA}

Abidin, Y. 2012. "Model Penilaian Otentik dalam Pembelajaran Membaca Pemahaman Berorientasi Pendidikan Karakter". Jurnal Pendidikan Karakter, Tahun II, Nomor 2, Juni 2012, hal 164-178.

Azra, A. 2012. Pendidikan Karakter: Peran Sekolah dan Keluarga.www.erlangga. co.id. Diunduh 12 Januari 2013.

Borg, W.R \& Gall, M.D. 1989. Educational Research: an Introduction (Fifth Edition). New York: Longman.

Idrus, M. 2012. "Pendidikan Karakter pada Keluarga Jawa". Jurnal Pendidikan Karakter, Tahun II, Nomor 2, Juni 2012, hal 118-130.

Iskandarwassid dan Sunendar. 2008. Strategi Pembelajaran Bahasa. Bandung: PT Rosdakarya.

Martha, I N. 2013. “Pengembangan Materi Ajar Bahasa Bali dengan NilaiNilai Lokal (Kearifan Lokal) Bali, dalam Pembelajaran Bahasa Bali, sesuai Kurikulum 2013". Empowering Language, Literature, and regional Culture in Increasing The Existence of Nation Culture and The Communication and Intensity among Nation. Proceedings The $3^{\text {rd }}$ International Conference of Regional Culture (KIBD-III). Ed. Nugrahani, dkk., hal 39-47.

Miles, M.B. dan A. Michael H. 1992. Analisis Data Kualitatif. Terjemahan Tjetjep Rohendi Rohidi. Jakarta: Universitas Indonesia Press.

Moleong, L. 1995. Metodologi Penelitian Kulitatif. Bandung: Remaja Rosdakarya.

Nurgiyantoro, B. 2001. Penilaian dalam Pengajaran Bahasa dan Sastra. Yogyakarta: BPFE

Padmosoekotjo. 1960. Ngengrengan Kasusastran Djawa I. Jogjakarta: Penerbit Hien Hoo Sing. 
Parera, J.D. 1996. Pedoman Kegiatan Belajar mengajar Bahasa Indonesia. Jakarta: Grasindo.

Sartini, N.W. 2009. “Menggali Kearifan Lokal Budaya Jawa Lewat Ungkapan (Bebasan, Saloka, dan Paribasan)". Jurnal Ungkapan Tradisional Jawa. Vol 5 No. 1, April 2009, hal 31-43.

Soehardi. 2002. "Nilai-Nilai Tradisi Lisan dalam Budaya Jawa" dalam Jurnal Humaniora Volume XIV, No. 3. Yogyakarta: Fakultas Ilmu Budaya Universitas Gadjah Mada.

Suciati, S. dan Ika S. 2014. "Program Televisi Komedi Pemicu Kekerasan Verbal Anak". Bahasa Ibu Pelestarian dan Pesona Bahasanya. Ed. Khak dkk., hal 622-635.

Sukadaryanto. 2001. Ungkapan Tradisioanal sebagai Salah Satu Sikap Masyarakat Jawa yang Merefleksi Nilai Pendidikan. Yogyakarta: Media Pressindo.
Sukadaryanto. 2013. "Moralitas dalam Serat Cemporet sebagai Bahan Ajar Membaca Sastra di SMA". Empowering Language, Literature, and regional Culture in Increasing The Existence of Nation Culture and The Communication and Intensity among Nation. Proceedings The $3^{\text {rd }}$ International Conference of Regional Culture (KIBD-III). Ed. Nugrahani, dkk., hal 202-209.

Sukiman. 2012. Pengembangan Media Pembelajaran. Yogyakarta: Pedagogia.

Tarigan, H.G. 2008. Menyimak sebagai Suatu Keterampilan Berbahasa (Edisi Revisi). Bandung:Angkasa.

Widyastuti, S.H. 2012. "Kandungan Nilai Moral dalam Ungkapan Tradisional Jawa dan Pepatah Cina". Litera. Volume II, Nomor 1, April 2012, hal 147-157. 